\title{
Sistem Pendukung Keputusan Wisata Kuliner Berbasis Gis Pada Perangkat Android
}

\author{
Okky Pamungkas H, Ragil Saputra, Panji Wisnu Wirawan
}

Ilmu Komputer / Informatika FSM Universitas Diponegoro

\begin{abstract}
Abstrak
Semarang merupakan kota yang memiliki banyak potensi pariwisata, salah satunya yaitu wisata kuliner. Sekarang ini, masyarakat masih mengalami kesulitan dalam menemukan lokasi kuliner yang sesuai dengan preferensi yang diinginkan seperti jenis makanan, harga makanan, lokasi dan fasilitas restoran.Perkembangan teknologi saat ini, informasi bisa didapatkan dimanapun dan kapan pun. Salah satunya yaitu dengan menggunakan smartphone bersistem operasi Android.Sistem Pendukung Keputusan Wisata Kuliner Berbasis GIS pada Perangkat Android dapat digunakan sebagai solusi untuk menentukan lokasi kuliner berdasarkan preferensi yang diinginkan. Metode yang digunakan dalam sistem pendukung keputusan ini adalah Simple Additive Weighting. Sistem ini menggunakan bahasa pemrograman Java untuk client dan bahasa pemrograman PHP untuk administrator, dengan database management system MySQL, dan didukung dengan peta digital Google Maps API. Hasil dari Sistem Pendukung Keputusan ini adalah rangking lokasi kuliner berdasarkan preferensi yang diinginkan dan letak lokasi kuliner tersebut pada Google Maps.
\end{abstract}

Kata Kunci: Kuliner, Sistem Pendukung Keputusan, Simple Additive Weighting, GIS, Android.

\section{Pendahuluan}

Semarang sebagai ibukota Provinsi Jawa Tengah, merupakan salah satu kota yang berkembang pesat di Indonesia. Dengan keberagaman dan keunikan potensi-potensi pariwisata yang ada di kota Semarang, tentunya hal ini menarik wisatawan untuk berwisata ke kota Semarang, Industri pariwisata di Jawa Tengah sendiri memiliki potensi ekonomi yang cukup tinggi per tahunnya[3]. Selain mengunjungi tempat- tempat bersejarah yang ada di Semarang, tentunya para wisatawan juga mencari tempat makan untuk memenuhi kebutuhan kuliner mereka. Sebagai kota besar yang terus berkembang, menjadikan Semarang memiliki jumlah penduduk yang cukup banyak dan terus bertambah. Dengan padatnya penduduk serta keanekaragaman suku dan ras menjadikan Semarang memiliki beragam jenis makanan atau kuliner.

Banyaknya lokasi wisata kuliner yang tersebar di kota Semarang tidak semuanya dapat diketahui oleh para wisatawan, dikarenakan kurangnyainformasi lokasi wisata kuliner. Dengan memanfaatkan kemajuan di bidang teknologi informasi yang sekarang semakin pesat, membangun suatu aplikasi sistem pendukung keputusan dapat membantu wisatawan dalam menentukan alternatif lokasi kuliner yang sesuai dengan kriteria. Selain itu informasi tersebut dapat digabungkan dengan pemetaan dimana lokasi wisata kuliner itu berada. Dengan demikian informasi yang diperoleh bukan hanya textual saja tetapi juga dalam bentuk spasial atau peta yang interaktif.

Dengan pesatnya perkembangan teknologi komunikasi nirkabel, SIG desktop yang konvensional memiliki kecenderungan tren yang jelas terhadap pengembangan komputasi mobile. Mobile GIS lebih banyak digunakan dalam semua jenis kegiatan. Mobile GIS sendiri memiliki keuntungan dari SIG desktop serta kenyamanan yang dimiliki perangkat mobile. Hal ini sangat berguna untuk memenuhi kebutuhan aplikasi untuk mendapatkan geo-information untuk apa saja, siapa saja, di mana saja serta kapan saja.

Dengan memperhatikan fakta tersebut, permasalahan yang dihadapi oleh wisatawan dapat diatasi dengan memanfaatkan fitur yang ada di perangkat mobile. Salah satunya yaitu Google Maps pada sistem operasi Android yang telah terintegrasi di dalamnya. Kemudian dapat dibangun suatu sistem pendukung keputusan berbasis GIS yang dapat memberikan informasi lokasi wisata kuliner kepada masyarakat secara efektif dan efisien. 


\section{Dasar Teori}

\subsection{Pengertian Sistem Pendukung Keputusan}

Sistem Pendukung Keputusan (SPK) adalah sistem berbasis komputer yang terdiri dari tiga komponen yang saling berinteraksi antara lain[22]:

1. Sistem bahasa yaitu mekanisme untuk memberikan komunikasi antara pengguna dan komponen SPK lain.

2. Sistem pengetahuan yaitu repositori pengetahuan domain masalah yang ada pada SPK, sebagai data atau sebagai prosedur.

3. Sistem pemrosesan masalah yaitu hubungan antara dua komponen lainnya, terdiri dari satu atau lebih kapabilitas manipulasi masalah umum yang diperlukan untuk pengambilan keputusan.

\subsection{Pengertian Sistem Informasi Geografis}

Menurut ESRI (Environmental System Research Institute), Sistem Informasi Geografis (GIS) atau Geographic Information System (GIS) adalah kumpulan yang terorganisir dari perangkat keras komputer, perangkat lunak, data geografis dan personil yang dirancang secara efisien untuk memperoleh, menyimpan, mengupdate, memanipulasi, menganalisis, dan menampilkan semua bentuk informasi yang bereferensi geografi [7].

\subsection{Simple Additive Weighting (SAW)}

Metode SAW sering juga dikenal dengan istilah metode penjumlahan terbobot. Konsep dasar metode SAW adalah mencari penjumlahan terbobot dari rating kinerja pada setiap alternatif pada semua atribut. Metode SAW membutuhkan proses normalisasi matriks keputusan (X) ke suatu skala yang dapat diperbandingkan dengan semua rating alternatif yang ada.[11]

Metode ini merupakan metode yang paling dikenal dan paling banyak digunakan orang dalam menghadapi situasi MADM (multiple attribute decision making). Metode ini mengharuskan pembuat keputusan menentukan bobot bagi setiap atribut. Skor total untuk sebuah alternatif diperoleh dengan menjumlahkan seluruh hasil perkalian antara rating dan bobot tiap atribut. Rating tiap atribut haruslah bebas dimensi yang artinya telah melewati proses normalisasi sebelumnya.

\subsection{Sistem Operasi Android}

Sistem operasi Android adalah sebuah sistem operasi untuk perangkat mobile yang menyertakan middleware (virtual machine) dan sejumlah aplikasi utama. Pada awalnya sistem operasi ini dikembangkan oleh sebuah perusahaan bernama Android, Inc. Dari sinilah awal mula nama Android muncul. Android Inc adalah sebuah perusahaan start-up kecil yang berlokasi di Palo Alto, California, Amerika Serikat yang didirikan oleh Andy Rubin bersama Rich Miner, Nick Sears, dan Chris White. Pada bulan juli 2005, perusahaan tersebut dieksekusi oleh Google dan para pendirinya bergabung ke Google. Andy Rubin sendiri kemudian diangkat menjadi Wakil Presiden divisi mobile dari Google.

Tujuan sistem operasi ini adalah untuk menyediakan platform yang terbuka, yang memudahkan orang mengakses internet menggunakan telepon seluler. Android juga dirancang untuk memudahkan pengembang aplikasi membuat aplikasi dengan batasan yang minim sehingga kreativitas pengembang menjadi lebih berkembang [2].

\section{Analisis dan Perancangan}

\subsection{Deskripsi Sistem}

Sistem Pendukung Keputusan Wisata Kuliner Berbasis GIS pada Perangkat Android atau bisa disebut SPANK merupakan sistem yang bertujuan menghasilkan informasi wisata kuliner berdasarkan kriteria dan bobot yang telah dimasukkan oleh pengguna dalam bentuk rangking. SPANK akan memandu dan memberikan informasi seputar lokasi wisata kuliner tujuan. Implementasi pada devices sesungguhnya menggunakan devices Android dengan operating system (OS) Gingerbread dikarenakan Android versi tersebut yang paling banyak dimiliki oleh masyarakat. Gambar 1 menunjukkan arsitektur Sistem Pendukung Keputusan Wisata Kuliner Berbasis GIS pada Perangkat Android yang dikembangkan. 


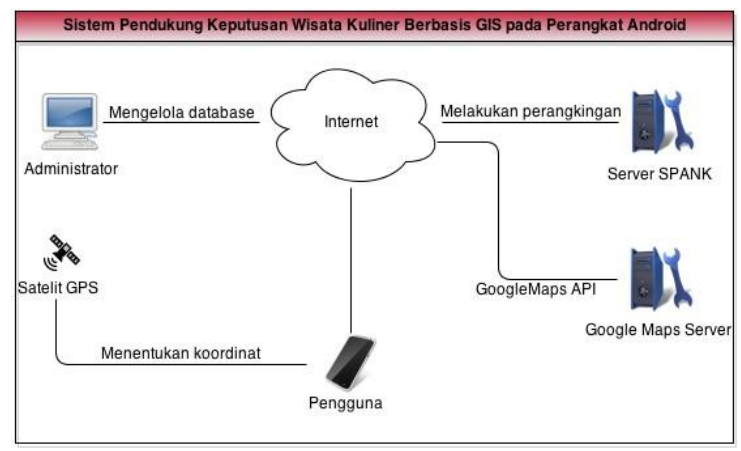

Gambar 1. Arsitektur SPANK

Pada arsitektur SPANK tersebut digambarkan pengguna yang menggunakan sistem ini melalui device Android. Ketika pengguna mengakses SPANK, sistem tersebut akan mengambil data ke server SPANK. Di dalam server tersebut terdapat file php sebagai web service dan database. Masukan dari pengguna akan dihitung terlebih dahulu oleh web service baru kemudian sistem mengakses database. Administrator terhubung langsung dengan server untuk pengolahan data. Administrator berperan mengelola data melalui halaman admin SPANK menggunakan browser komputer maupun laptop. Pengolahan data tersebut meliputi menambah, mengubah, dan menghapus data. Data yang dikelola administrator berupa data administrator, restoran, dan makanan.

\subsection{Use case Diagram}

Use case diagram disusun berdasarkan daftar actor dan daftar use case dan disusun berdasarkan hubungan keduanya, use case diagram sistem dapat dilihat pada Gambar 2. Use case merupakan deskripsi urutan tindakan yang dilakukan sistem yang berpengaruh kepada actor dari sistem. Terdapat lima use case dalam sistem, yaitu login, kelola data, tentukan preferensi kuliner, hitung nilai masukan dengan metode SAW, dan lihat lokasi.

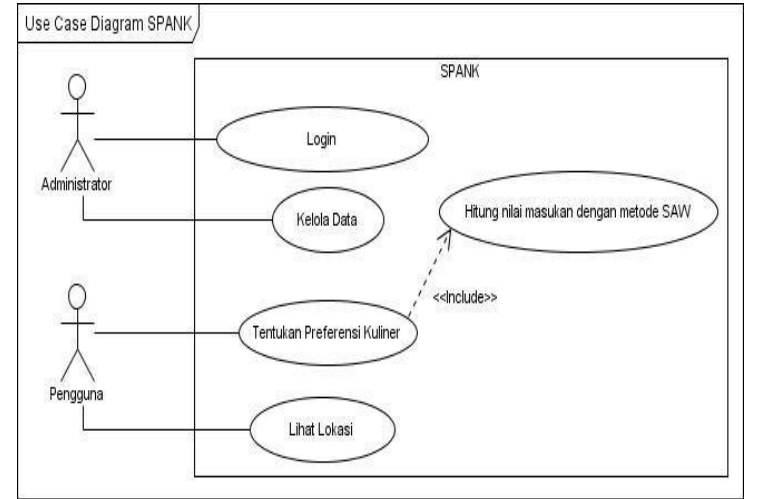

Gambar 2. Use Case Diagram Sistem

\subsection{Activity Diagram}

Activity diagram menggambarkan berbagai aliran aktivitas yang terjadi di dalam sistem, titik awal dari masing-masing aliran, keputusan yang mungkin terjadi, dan akhir dari aliran aktivitas tersebut. Alur proses sistem pendukung keputusan wisata kuliner berbasis GIS pada perangkat android, digambarkan pada activity diagram pada Gambar

3.

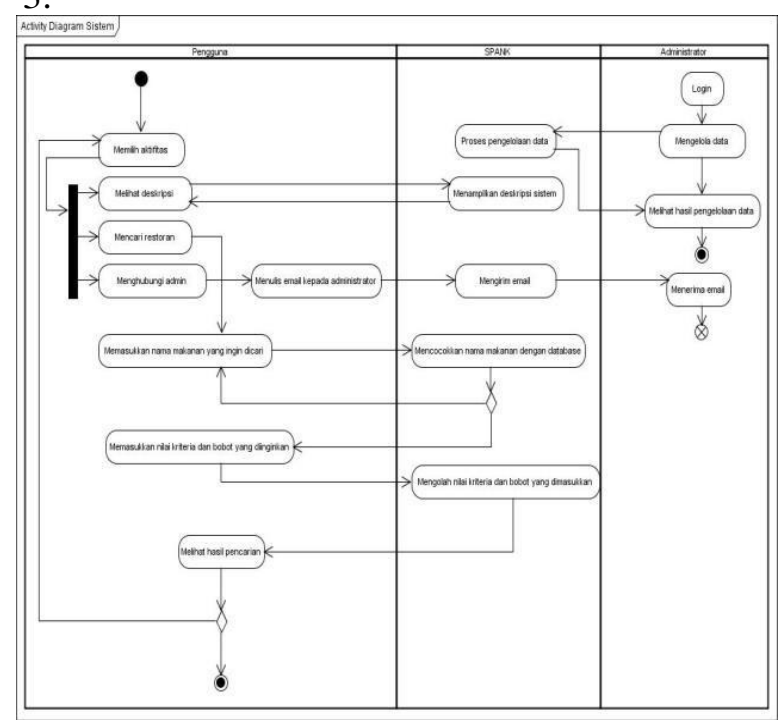

Gambar 3. Activity Diagram Sistem

Terlihat pada activity diagram tersebut pengguna atau wisatawan dan administrator memiliki aktifitas masing-masing.

Wisatawan atau pengguna :

1. Melihat deskripsi

SPANK akan menampilkan deskripsi sistem kepada pengguna dalam bentuk text.

2. Mencari restoran 
Dalam aktivitas mencari restoran, pengguna memasukkan nama makanan yang akan dicari kemudian SPANK akan melakukan pengecekan apakah makanan tersebut ada dalam database. Setelah makanan ditemukan dalam database, pengguna memasukkan nilai kriteria dan bobot yang diinginkan. Ketika proses itu selesai SPANK akan menampilkan list view restoran berdasarkan hasil perangkingan serta menampilkan lokasi restoran dan lokasi pengguna berdasarkan posisinya $(\mathrm{x}, \mathrm{y})$ pada peta.

3. Menghubungi admin

Pengguna dapat menghubungi administrator SPANK dengan mengirim pesan dalam bentuk email

\section{Administrator :}

1. Mengelola data

Setelah melakukan login, administrator mengolah data berupa data restoran, makanan, serta masing-masing harganya. Pengelolaan yang dilakukan oleh administrator meliputi menambah data, mengubah data, dan menghapus data. Kemudian sistem informasi database SPANK akan memproses pengolahan data yang dilakukan oleh administrator.

2. Menerima email

Administrator menerima email yang ditulis oleh wisatawan atau pengguna.

\subsection{Perancangan Basis Data}

DBMS yang digunakan pada Sistem Pendukung Keputusan Wisata Kuliner Berbasis GIS pada Perangkat Android ini adalah basis data relasional. Oleh karena itu, perlu dilakukan mapping dari class diagram entity ke skema basis data relasional. Hasil mapping tersebut dapat dilihat pada Tabel 1. Terdapat 5 tabel yang dibuat pada basis data pengembangan Sistem Pendukung Keputusan Wisata Kuliner Berbasis GIS pada Perangkat Android. Hasil perancangan dapat dilihat pada Gambar 4.
Tabel 1. Hasil Identifikasi Tabel

\begin{tabular}{|c|l|l|}
\hline No & Nama Entity Class & \multicolumn{1}{|c|}{ Nama Tabel } \\
\hline 1. & administrator & administrator \\
\hline 2. & group & group \\
\hline 3. & restoran & restoran \\
\hline 4. & sajian & sajian \\
\hline & makanan & makanan \\
\hline
\end{tabular}

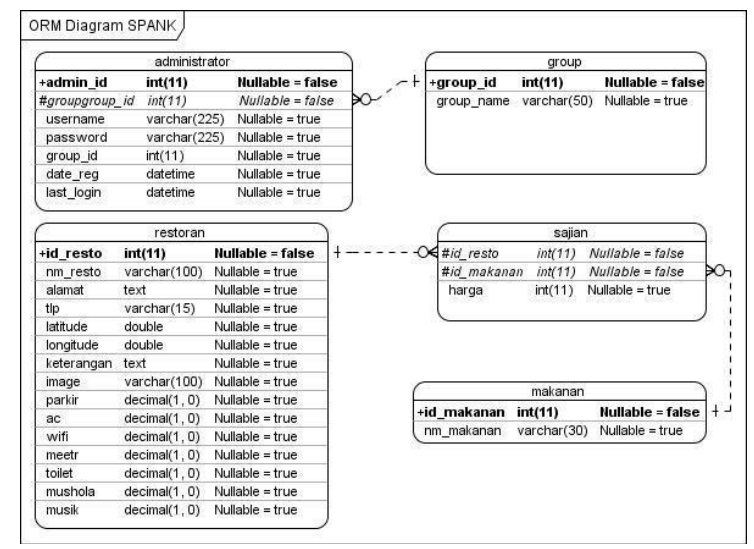

Gambar 4. ORM Diagram Sistem

\subsection{Perancangan Antarmuka}

Perancangan antarmuka digunakan untuk merepresentasikan bentuk Sistem Pendukung Keputusan Wisata Kuliner Berbasis GIS pada Perangkat Android. Halaman pertama dari perancangan antarmuka SPANK adalah tab home, yang ditunjukan pada Gambar 5.

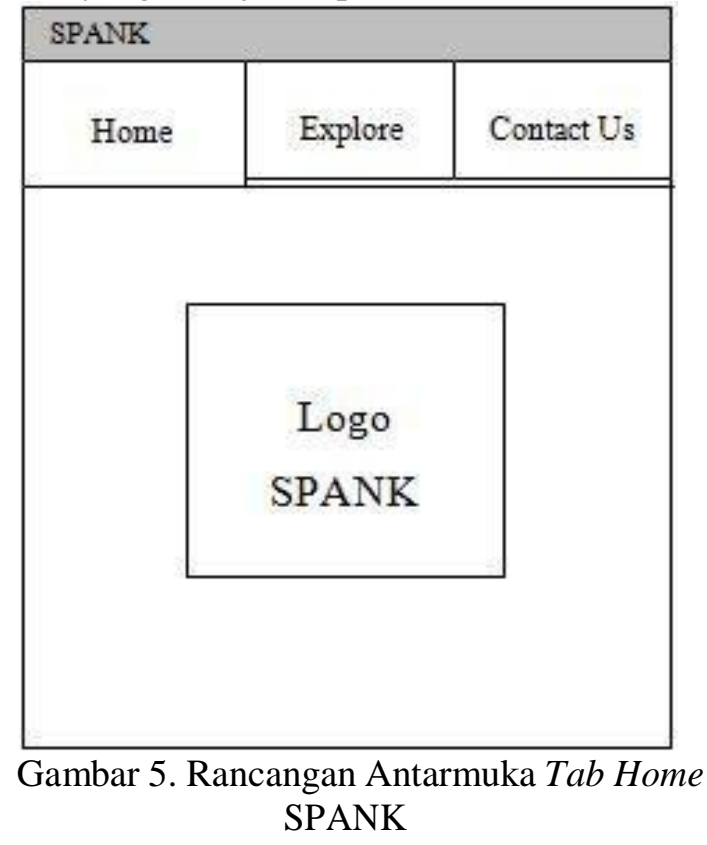




\section{Implementasi dan Pengujian}

\subsection{Implementasi Basis Data}

Implementasi basis data merupakan transformasi rancangan data yang dihasilkan dari proses perancangan basis data menjadi suatu basis data untuk Sistem Pendukung Keputusan Wisata Kuliner Berbasis GIS pada Perangkat Android (SPANK).

Berikut adalah implementasi basis data untuk SPANK :

\section{1) Administrator}

Implementasi basis data dari tabel administrator ditunjukan pada tabel 2 .

Tabel2. Implementasi basis data administrator

\begin{tabular}{|l|l|l|}
\hline No & \multicolumn{1}{|c|}{ Field } & \multicolumn{1}{c|}{ Tipe } \\
\hline 1. & admin_id & Int \\
\hline 2. & username & Varchar(255) \\
\hline 3. & password & Varchar(255) \\
\hline 4. & group_id & Int \\
\hline 5. & date_reg & Datetime \\
\hline 6. & login_last & Datetime \\
\hline
\end{tabular}

\section{2) Group}

Implementasi basis data dari tabel group ditunjukan pada tabel 3 .

Tabel 3. Implementasi basis data group

\begin{tabular}{|c|l|l|l|}
\hline No & Fiel & \multicolumn{1}{|c|}{$T$} & Keteranga \\
\hline 1. & group_id & Int & $\begin{array}{l}\text { Primary } \\
\text { key, } \\
\text { auto_incr }\end{array}$ \\
\hline 2. & group name & Varchar(50) & \\
\hline
\end{tabular}

3) Makanan

Implementasi basis data dari tabel makanan ditunjukan pada tabel 4 .

Tabel 4. Implementasi basis data makanan

\begin{tabular}{|c|c|l|l|}
\hline No & \multicolumn{1}{|c|}{ Fiel } & \multicolumn{1}{|c|}{ T } & Keteranga \\
\hline 1. & id_makanan & Int & $\begin{array}{l}\text { Prima } \\
\text { ry key, } \\
\text { auto_incr }\end{array}$ \\
\hline 2. & nm makana & Varchar(30) & \\
\hline
\end{tabular}

4) Restoran

Implementasi basis data dari tabel restoran ditunjukan pada tabel 5.
Tabel 5. Implementasi basis data restoran

\begin{tabular}{|c|c|c|c|}
\hline No & Field & Tipe & Keterangan \\
\hline 1. & id_resto & Int & $\begin{array}{l}\text { Primary key, } \\
\text { auto_increm } \\
\text { ent }\end{array}$ \\
\hline 2. & nm_resto & Varchar(100) & \\
\hline 3. & alamat & Varchar(100) & \\
\hline 4. & tlp & Varchar(15) & \\
\hline 5. & lat & Double & \\
\hline 6. & longi & Double & \\
\hline 7. & keterangan & Text & \\
\hline 8. & image & Varchar(100) & \\
\hline 9. & parkir & Enum(,tidake, & \\
\hline 10. & $\mathrm{ac}$ & Enum(,tidak ${ }^{\text {ee }}$, ada $\left.^{\text {ee }}\right)$ & \\
\hline 11. & wifi & Enum(,tidak ${ }^{\text {ee }}$, ada $\left.^{e e}\right)$ & \\
\hline 12. & meetr & Enum(,tidak ${ }^{\text {ee }}$, ada $\left.^{e e}\right)$ & \\
\hline 13. & toilet & Enum(,tidak $\left.{ }^{e e},{ }^{e c}{ }^{e e}\right)$ & \\
\hline 14. & mushola & Enum(,tidak & \\
\hline 15 & musik & Enum(,tidak"e "eada"e & \\
\hline
\end{tabular}

\section{5) Sajian}

Implementasi basis data dari tabel sajian ditunjukan pada tabel 6 .

Tabel 6. Implementasi basis data sajian

\begin{tabular}{|c|l|l|l|}
\hline $\mathrm{Tab}$ & \multicolumn{1}{|c|}{ Field } & \multicolumn{1}{c|}{$\mathrm{T}$} & Keteranga \\
\hline 1. & id resto & Int & Foreign \\
\hline 2. & id makana & Int & Foreign \\
\hline 3. & harga & Int(11) & \\
\hline
\end{tabular}

\subsection{Implementasi Antarmuka}

Pada sub bab ini disajikan implementasi antarmuka dari use case yang telah diidentifikasi pada workflow sebelumnya. Halaman pertama dari implementasi antarmuka SPANK adalah tab home, yang ditunjukan pada gambar 6 .

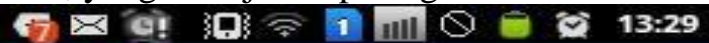
Spank v1.0
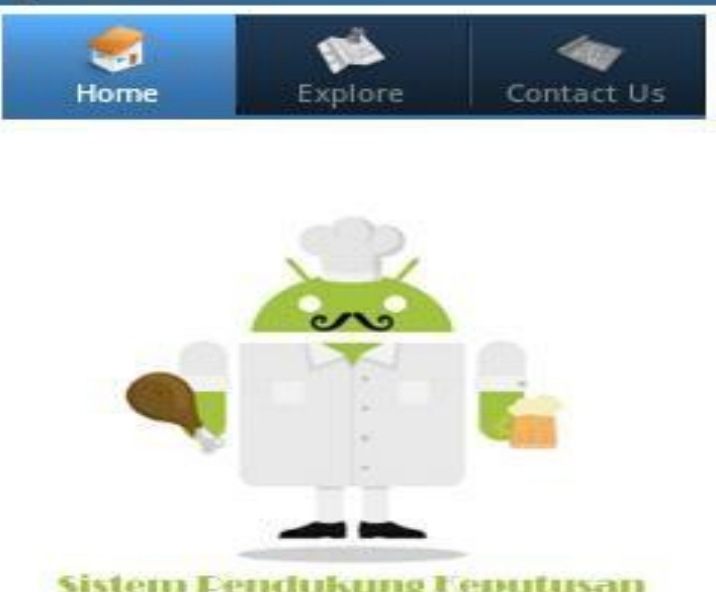

Gambar 6. Tampilan Tab Home 
SPANK Berikut ini adalah mplementasi antarmuka untuk use case Login, Kelola Data, Tentukan Preferensi Kuliner, Hitung Nilai Masukan Dengan Metode SAW, dan Lihat Lokasi.

1) Login

Implementasi antarmuka use case Login dapat dilihat pada Gambar 7.

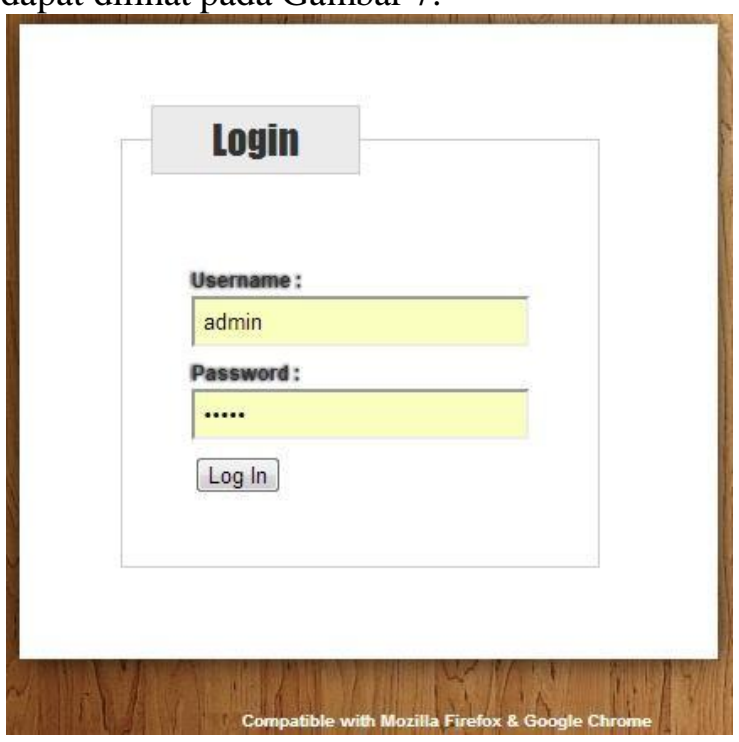

Gambar 7. Tampilan Halaman Login

\section{2) Kelola Data}

Implementasi antarmuka use case kelola data terbagi menjadi beberapa tampilan meliputi kelola data administrator, kelola data restoran, dan kelola data makanan.

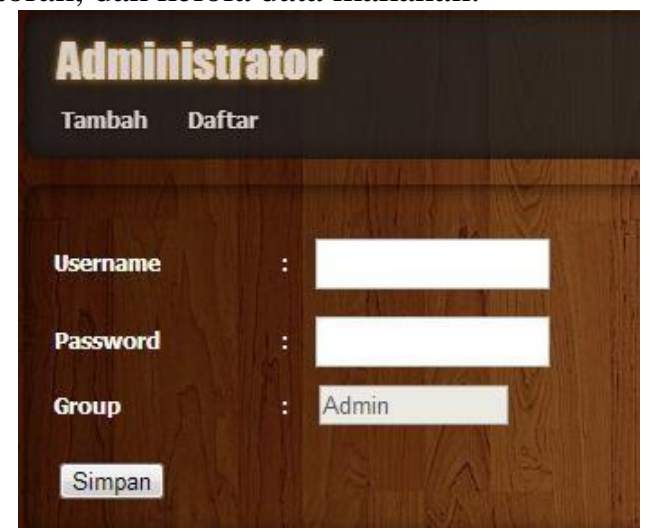

Gambar 8. Tampilan Halaman Tambah Data Administrator

\section{Malranan}

Tambah Makanan

Daftar Makanan

Nama Makanan

\section{Simpan}

Gambar 9. Tampilan Halaman Tambah Data Makanan

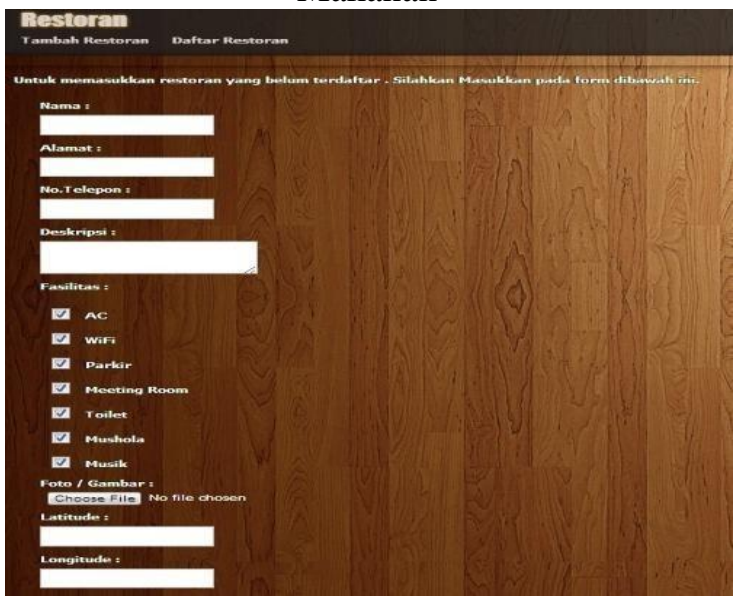

Gambar 10. Tampilan Halaman Tambah Data Restoran

\section{3) Tentukan Preferensi Kuliner} Implementasi antarmuka tentukan preferensi kuliner terbagi menjadi beberapa bagian berdasarkan tahapan yang ada. Berikut implementasi antarmuka tentukan preferensi kuliner dari use case tentukan preferensi kuliner

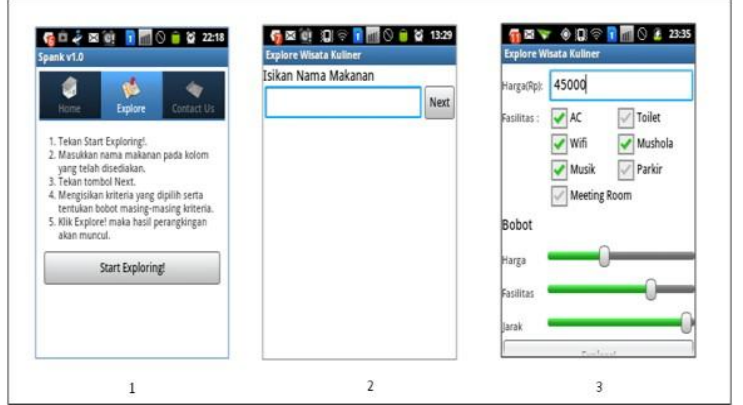

Gambar 11. Tampilan Antarmuka Tentukan Preferensi Kuliner

\section{4) Lihat Lokasi}

Implementasi antarmuka lihat lokasi terbagi menjadi beberapa bagian berdasarkan 
tahapan yang ada. Berikut implementasi antarmuka lihat lokasi dari use case lihat lokasi

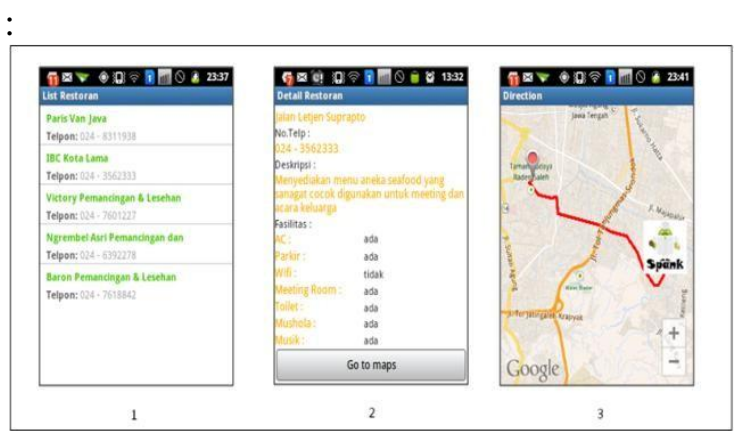

Gambar 12. Tampilan Antarmuka Lihat Lokasi

\subsection{Rencana Pengujian}

Rencana pengujian SPANK dapat dilihat pada Tabel 7. Terdapat 4 use case yang akan diuji yaitu use case login, kelola data, tentukan preferensi kuliner, dan lihat lokasi.

Tabel 7. Rencana Pengujian

\begin{tabular}{|c|c|c|c|c|}
\hline No & Use Case & Pengujian & $\begin{array}{c}\text { Jenis } \\
\text { Pengujian }\end{array}$ & $\begin{array}{c}\text { Identifikasi } \\
\text { Pengujian }\end{array}$ \\
\hline \multirow{2}{*}{1.} & \multirow{2}{*}{ Login } & Skenario Utama 1-3 & Black Box & U-1-01 \\
\hline & & Skenario Abnormal & Black Box & $\mathrm{U}-1-02$ \\
\hline \multirow{4}{*}{2.} & \multirow{4}{*}{ Kelola Data } & Skenario Utama 1-2 & Black Box & $\mathrm{U}-2-01$ \\
\hline & & Skenario Utama 3-4 & Black Box & $\mathrm{U}-2-02$ \\
\hline & & Skenario Utama 5-6 & Black Box & $\mathrm{U}-2-03$ \\
\hline & & Skenario Abnormal & Black Box & $\mathrm{U}-2-04$ \\
\hline \multirow{3}{*}{3.} & \multirow{3}{*}{ Tentukan Preferensi Kuliner } & Skenario Utama 1 & Black Box & U-3-01 \\
\hline & & Skenario Utama 2-3 & Black Box & $\mathrm{U}-3-02$ \\
\hline & & Skenario Abnormal & Black Box & U-3-03 \\
\hline \multirow{4}{*}{4.} & \multirow{4}{*}{ Lihat Lokasi } & Skenario Utama 1-2 & Black Box & $\mathrm{U}-4-01$ \\
\hline & & Skenario Utama 3-4 & Black Box & $\mathrm{U}-4-02$ \\
\hline & & Skenario Utama 5-6 & Black Box & U-4-03 \\
\hline & & Skenario Abnormal & Black Box & U-4-04 \\
\hline
\end{tabular}

\subsection{Pelaksanaan Pengujian}

Pelaksanaan pengujian dilakukan dengan cara mengimplementasikan rencana pengujian yang telah disusun. Tabel hasil uji dapat dilihat pada Tabel 8 - Tabel 11 .

Tabel 8. Tabel Hasil Uji Login

\begin{tabular}{|l|l|l|l|}
\hline Identifikasi & Deskripsi & Prosedur Pengujian & Kesimpulan \\
\hline U-1-01 & $\begin{array}{l}\text { Pengujian } \\
\text { login }\end{array}$ & $\begin{array}{l}\text { Memasukan username } \\
\text { dan password untuk } \\
\text { login kedalam sistem }\end{array}$ & Diterima \\
\hline U-1-02 & $\begin{array}{l}\text { Pengujian } \\
\text { login dengan } \\
\text { username dan } \\
\text { password } \\
\text { yangtidak ada } \\
\text { di sistem }\end{array}$ & $\begin{array}{l}\text { Memasukan username } \\
\text { dan password yang } \\
\text { tidak ada di dalam } \\
\text { sistem untuk login ke } \\
\text { dalam sistem }\end{array}$ & Diterima \\
\hline
\end{tabular}

Tabel 9. Tabel Hasil Uji Kelola Data

\begin{tabular}{|l|l|l|l|}
\hline Identifikasi & Deskripsi & Prosedur Pengujian & Kesimpulan \\
\hline U-2-01 & $\begin{array}{l}\text { Pengujian } \\
\text { penambahan } \\
\text { data }\end{array}$ & $\begin{array}{l}\text { - Mengisikan data } \\
\text { secara lengkap } \\
\text { - Menyimpan data }\end{array}$ & Diterima \\
\hline U-2-02 & $\begin{array}{l}\text { Pengujian } \\
\text { pengubahan } \\
\text { data }\end{array}$ & $\begin{array}{l}\text { - Mengubah data } \\
\text { - Menyimpan } \\
\text { perubahan data }\end{array}$ & Diterima \\
\hline U-2-03 & $\begin{array}{l}\text { Pengujian } \\
\text { penghapusan } \\
\text { data }\end{array}$ & - Menghapus data & Diterima \\
\hline U-2-04 & $\begin{array}{l}\text { Pengujian } \\
\text { Memasukkan } \\
\text { data yang } \\
\text { tidak lengkap } \\
\text { pada form } \\
\text { tambah data }\end{array}$ & $\begin{array}{l}\text { - Mengisikan data } \\
\text { secara tidak lengkap }\end{array}$ & Diterima \\
\hline
\end{tabular}

Tabel 10. Tabel Hasil Uji Tentukan Preferensi Kuliner

\begin{tabular}{|l|l|l|l|}
\hline Identifikasi & \multicolumn{1}{|c|}{ Deskripsi } & Prosedur Pengujian & Kesimpulan \\
\hline U-3-01 & $\begin{array}{l}\text { Pengujian } \\
\text { memasukkan } \\
\text { nama makanan }\end{array}$ & $\begin{array}{l}\text { Memasukkan nama } \\
\text { makanan pada text box }\end{array}$ & Diterima \\
\hline U-3-02 & $\begin{array}{l}\text { Pengujian } \\
\text { memasukkan } \\
\text { nilai kriteria dan } \\
\text { bobot }\end{array}$ & $\begin{array}{l}\text { Memasukkan nilai } \\
\text { kriteria dan bobot } \\
\text { secara lengkap }\end{array}$ & Diterima \\
\hline U-3-03 & $\begin{array}{l}\text { Pengujian } \\
\text { memasukkan } \\
\text { data yang tidak } \\
\text { lengkap pada } \\
\text { form masukan } \\
\text { kriteria dan bobot }\end{array}$ & $\begin{array}{l}\text { Memasukkan nilai } \\
\text { kriteria dan bobot } \\
\text { secara tidak lengkap }\end{array}$ & Diterima \\
\hline
\end{tabular}

Tabel 11. Tabel Hasil Uji Lihat Lokasi

\begin{tabular}{|l|l|l|l|}
\hline Identifikasi & \multicolumn{1}{|c|}{ Deskripsi } & Prosedur Pengujian & Kesimpulan \\
\hline U-4-01 & $\begin{array}{l}\text { Pengujian } \\
\text { menampilkan list } \\
\text { view wisata } \\
\text { kuliner hasil } \\
\text { perangkingan }\end{array}$ & $\begin{array}{l}\text { Memasukkan nilai } \\
\text { kriteria dan bobot }\end{array}$ & Diterima \\
\hline U-4-02 & $\begin{array}{l}\text { Pengujian } \\
\text { menampilkan } \\
\text { detailrestoran }\end{array}$ & $\begin{array}{l}\text { Memilih salah satu list } \\
\text { view restoran }\end{array}$ & Diterima \\
\hline U-4-03 & $\begin{array}{l}\text { Pengujian } \\
\text { menampilkan } \\
\text { peta lokasi }\end{array}$ & $\begin{array}{l}\text { Menekan tombol "go to } \\
\text { maps" }\end{array}$ & Diterima \\
\hline U-4-04 & $\begin{array}{l}\text { Pengujian } \\
\text { menampilkan } \\
\text { peta lokasi } \\
\text { dimana GPS } \\
\text { tidak aktif }\end{array}$ & $\begin{array}{l}\text { Menekan tombol "go to } \\
\text { maps" }\end{array}$ & Diterima \\
\hline
\end{tabular}

\subsection{Evaluasi Pengujian}

Dari deskripsi dan hasil uji yang disajikan pada Tabel 8 - Tabel 11, dapat dilihat bahwa pengujian yang telah dilakukan dapat diterima. Tabel-tabel deskripsi dan hasil uji pada Tabel 8 - Tabel 11 menunjukkan bahwa semua identifikasi pengujian yang disusun pada Tabel 4.6 telah diujikan dan hasil yang didapat sesuai dengan hasil yang diharapkan dan dapat disimpulkan bahwa perilaku sistem telah berjalan sesuai dengan apa yang didefinisikan pada core workflow definisi kebutuhan. Dari 
hasil pengujian, dapat diketahui bahwa SPANK ini telah memenuhi untuk :
a. Login
b. Kelola data
c. Tentukan preferensi kuliner
d. Hitung nilai masukan dengan metode SAW
e. Lihat Lokasi

\section{Kesimpulan dan Saran}

\subsection{Kesimpulan}

Kesimpulan yang dapat diambil dalam pengerjaan tugas akhir ini adalah:

a. Dihasilkan Sistem Pendukung Keputusan Wisata Kuliner Berbasis GIS pada Perangkat Androidyang diharapkan dapat membantu wisatawan dalam menentukan tujuan wisata kuliner berdasarkan kriteria yang dipilih.

b. Aplikasi ini menggunakan Distance Matrix API untuk menentukan jarak antara posisi pengguna dengan lokasi tujuan, sehingga jarak yang dihasilkan merupakan jarak jalan yang ditempuh pengguna bukan hanya jarak dari masing - masing koordinat yang ditarik garis lurus.

c. Sistem ini menggunakan metode Simple Additive Weighting sehingga hasil perhitungan yang didapat berupa perangkingan lokasi kuliner dari yang paling sesuai.

\subsection{Saran}

Sistem Pendukung Keputusan Wisata Kuliner Berbasis GIS pada Perangkat Android ini masih memerlukan pengembangan lebih lanjut, seperti:

a. Menambahkan fitur Rekomendasi. Fitur tersebut akan memberikan informasi berupa restoran yang dapat direkomendasikan ke pengguna berdasarkan kategori tertentu tanpa harus menerima masukkan dari pengguna.

b. Aplikasi ini dikembangkan untuk seluruh device Android dengan berbagai versi sistem operasi.

\section{REFERENSI}

[1] Ambler, S.W.,2012, "Mapping Objects to Relational Databases: O/R Mapping In
Detail", diakses dari www.agiledata.org pada tanggal 10April 2013

[2] Andry, 2011, "Android A sampai $Z$ ',Group Of Magazine, Jakarta

[3] Anonim, "Banyaknya Pengunjung Obyek Wisata/Taman Rekreasi Menurut Kabupaten/Kota di Jawa Tengah Tahun2011", diakses dari http://jateng.bps.go.id pada tanggal 18 Oktober 2012 pukul 11.00 WIB

[4] Arlow, J. dan Neustadt, I., 2002, " $U M L$ and The Unified Process", Addison Wesley, Boston

[5] Booch, G., 2007, "Object-Oriented Analysis and Design with ApplicationsThird Edition", Addison Wesley, Boston

[6] Elmashri, R., dan Navathe, S.B.,"Fundamental of Database Systems, Fourth Edition", Addison Wesley, Boston

[7] Harmon, J.E. dan Anderson, S.J., 2003, "Design and Implementation of Geographic Information System", John Wiley and Sons, New Jersey

[8] Hunt, J., 2003, "Guide to the Unified Process featuring UML, Java and Design Patterns", Springer, London

[9] Jacobson, I., Booch, G., 1999, "The Unified Software Development Process", Addison Wesley, Boston

[10] Jogiyanto, H.M., 2003, "Sistem TeknologiInformasiEdisi 1", Andi, Yogyakarta

[11] Kusumadewi, S. dan Hartanti, S., 2006,"Fuzzy Multi-Atribute Decision Making(Fuzzy MADM)", Graha Ilmu, Yogyakarta [12] Nazruddin, S.H., 2011, "Pemrograman Aplikasi Mobile Smartphone dan Tablet PC Berbasis Android", Informatika, Bandung

[13] Nugroho, A., 2010, "Rekayasa Perangkat Lunak Berorientasi Objek dengan Metode USDP (Unified Software Development Process)", Andi, Yogyakarta

[14] Oracle, 2012, "Overview of the MySQL Database Management System", diakses dari 
http://dev.mysql.com/doc/refman/5.0/en/w hat-is.html pada tanggal 2April 2013

[15] Prahasta, E., 2002, "Konsep-konsep Dasar Sistem Informasi Geografis", Informatika, Bandung

[16] Riyanto P.E.P. dan Hendi I., 2009, "Pengembangan Aplikasi Sistem Informasi Geografis Berbasis Desktop dan Web", Gava Media, Yogyakarta

[17] Rumbaugh, J., Jacobson, I., dan Booch, G.,1999, "The Unified Modelling Language Reference Manual", Addison Wesley, Boston

[18] Siswanto., 2011, "Sistem Informasi Geografis Objek Wisata Menggunakan Google Maps API Studi Kasus Kabupaten Mojokerto",Politeknik Elektronika Negeri Surabaya, Surabaya
[19] Soetopo, A., 2001, "Analisis dan Desain Berorientasi Objek", J\&J Learning,Yogyakarta

[20]Sommerville, I.F., 2000, "Software Engineering6th Edition”, Erlangga, Jakarta

[21] Therestia, J., 2010, "Implementasi Mobile GIS Pada Navigasi Jalan Menggunakan PDA Pada Kabupaten Sleman", Yogyakarta

[22] Turban, E., Aronso, J.E., dan Liang, T.P., 2005, "Decision Support System andn Intelligent System", Andi, Yogyakarta

[23] Zhong, H., Jianping, W.U., dan Ping L.I.,2010, "Mobile And Wireless GIS Based Upon Independent Development",East China Normal University, Shanghai 
